\title{
유산소, 저항성, 균형 운동 프로그램이 허약 여성노인의 골격근 지수, 기능적 체력 및 건강관련 삶의 질에 미치는 영향
}

강설중 ${ }^{1 *} \cdot$ 김종휴 ${ }^{2)} \cdot$ 고광준 ${ }^{3)}$

1) 창원대학교 2) 우석대학교 3) 카톨릭대학교

\begin{abstract}
Seol-Jung Kang · Joung-Hyu Kim · Kwang-Jun Ko. Effects of Aerobic, Resistance, Balance Exercise Program on Skeletal Muscle Index, Functional Fitness, and Health-Related Quality of Life in Frail Elderly Women. KINESIOLOGY, 2015, 17(4): 9-20. [PURPOSE] The purpose of this study was to investigate the effects of aerobic, resistance, balance exercise program on skeletal muscle index, functional fitness, and health-related quality of life in frail elderly women. [METHODS] The subjects were comprised of 18 frail elderly women(exercise group, $\mathrm{n}=9$; control group, $\mathrm{n}=9$ ). The exercise program performed the aerobic exercise(20 minutes), resistance exercise(20 minutes), and balance exercise(10 minutes) a day, 3 days per week, for 12 weeks. The changes of body composition, fitness, health-related quality of life(SF-36) were measured and analyzed at pre- and post- exercise program for verifying the exercise effectiveness. [RESULTS] In body composition body weight $(p<.01)$, and $\%$ fat $(p<.001)$ were significantly decreased, but skeletal muscle mass and skeletal muscle index were not changed. In functional fitness, $\mathrm{VO}_{2} \max (p<.01)$, grip strength $(p<.001)$, arm $\operatorname{curl}(p<.001)$, chair sit to $\operatorname{stand}(p<.001)$, back $\operatorname{scratch}(p<.05)$, and chair sit \& reach $(p<.01)$ were significantly increased and timed up \& go $(p<.01)$ were significantly decreased. In SF-36, physical functioning $(p<.01)$, body pain $(p<.001)$, general health $(p<.001)$, role-emotional $(p<.05)$, and mental health $(p<.01)$ were significantly increased. [CONCLUSIONS] These findings suggest that combination of aerobic, resistance and balance exercise program showed the beneficial effects on functional fitness and SF-36 in frail elderly women.
\end{abstract}

Key words : exercise program, frail elderly women, skeletal muscle index, functional fitness, health-related quality of life 주요어 : 운동 프로그램, 허약 여성노인, 골격근 지수, 기능적 체력, 건강관련 삶의 질

\section{서론}

전 세계적으로 평균수명 연장에 따른 노인의 인구 비율이 급속하게 증가하고 있는 추세이다. UN(2012)에 따르면 65세 이상 노인의 인구가 전체 인구에서 차지하 는 비율이 $7 \%$ 이상이면 해당 국가를 고령화 사회(aging society)로 분류하고 있다. 대다수 $\mathrm{OECD}$ 국가도 고령화 사회이며, 한국 역시 2000년에 고령화 사회로 진입하였 다. 고령화 사회의 이슈 중 주된 관심은 건강수명 연장 혹은 건강한 노화(healthy aging)이다. 하지만 통계청 자료에 따르면 2005년 기준으로 평균수명은 78.6세이지 만 건강수명은 68.6세에 불과한 것으로 나타났다(Korea Institute for Health and Social Affairs, 2007). 이는 노 년기에 약 10 년 이상을 허약과 질병으로 인한 와병 상
태로 생활하게 된다고 볼 수 있다. 최근 노인 신체활동 증진대책 정책방안 보고서(Ministry of Health and Welfare Affairs, 2008)에 따르면 65세 이상 노인 6명 중 1 명은 건강노인이 아닌 허약노인(frail elderly)으로 분 류되고 있으며, 앞으로 더욱 증가할 것으로 예측하고 있다. 이에 고령화 사회에서 노인건강을 위협하는 허약 에 대한 관심이 높아지고 있다.

허약은 노화와 관련된 생리학적 취약성(age-related physiologic vulnerability)으로 정상 노화와 유사하게 기능적 예비능력(functional reserve) 저하를 일으킴에 도 불구하고, 기능적 쇠퇴가 더욱 빠르게 촉진된다 (Femia et al., 2001). 그 결과, 허약노인은 향후 수개 월 이내 신체기능의 제한과 장애 및 사망 위험도 높 아지게 된다(Fried et al., 2001; Ensrud et al., 2007).

* 교신저자: sjkang803@hanmail.net 
허약을 초래하는 병태생리학적 기전을 설명할 때 골 격근육량 감소로 인한 근육감소증(sarcopenia)이 중심 이 되고 있다(Cruz-Jentoft et al., 2010). 근육감소증의 임상적 정의가 되는 체중에서 골격근육량이 차지하는 골격근 지수(skeletal muscle index)가 낮으면 각종 기 능장애와 사망 위험 증가와 관련됨을 확인되고 있다 (Janssen et al., 2002; Visser \& Schaap, 2011).

또한 허약노인의 근육감소증에서 수반되는 근력 감 소는 신체적 기능을 저하시켜 독립적인 생활을 어렵 게 하는 요인이 되고 있다(Rikli \& Jones, 2001; Scott et al., 2014). 선행 연구에 의하면 허약노인은 건강노 인에 비해 신체활동에 필요한 근력이외에도 심폐지구 력, 유연성, 평형성, 민첩성 등의 기능적 체력이 저하 되어 있는 것으로 나타났다(Park et al., 2015; Waston et al., 2006). 이러한 기능적 체력저하는 일상생활수행 능력을 제한시키며 건강수준을 나타내는 지표인 삶의 질도 낮추게 하는 요인이 되고 있다(Put et al., 2007; Masel et al., 2009; Yim \& No, 2010). 이처럼 허약노 인은 신체기능 저하뿐만 아니라 주관적 건강상태인 삶의 질에도 부정적인 영향을 미치게 됨을 알 수 있 다. 이에 허약 노인의 기능적 체력과 건강관련 삶의 질을 높이는 중재방안이 필요하다.

운동은 허약노인의 중재방안으로서 건강한 노후를 영위하는데 필수적이며 근육감소증 예방과 기능적 체 력을 높이기 위한 핵심적인 요소로 제시되고 있다 (Fairhall et al., 2008; Nelson et al., 2007). 더욱이 운 동과 신체활동 증진은 노년기 삶의 질도 드높이는 주 된 요인이 되고 있다(Rejeski \& Mihalko, 2001). 허약 노인의 운동 프로그램 중 유산소 운동은 심폐기능과 골격근의 산화 능력을 높이며, 저항성 운동은 골격근 육량과 근력을 증진시켜 근육감소증 예방에 효과적이 다(ACSM, 1988; Burton \& Sumukadas, 2010; Koopman \& van Loon 2008). 또한 허약노인은 근신 경계의 기능저하로 균형 장애 문제도 나타나기 때문 에 균형 운동도 권고되고 있다(Lord et al., 1991; Madureira et al., 2007). 그러므로 허약노인의 운동 프로그램은 심폐계와 근골격계, 근신경계 기능을 전반 적으로 높여 독립적으로 일상생활을 수행하는 능력을 도모하는 것이 중요하다(WHO, 2010).

그러나 허약노인과 운동 프로그램에 대한 선행연구
의 경우 저항성 운동(Sakato et al., 2007; Sun et al, 2008), 복합운동 형태인 유산소 운동과 저항성 운동 (Park et al., 2006) 혹은 저항성 운동과 균형 운동(Gill et al., 2002; Helbostad et al., 2004) 등을 실시하여 신 체조성과 기능적 체력 변화 등에 대한 효과를 검증하 였다. 반면 허약노인에서 권고되고 있는 유산소 운동, 저항성 운동, 균형 운동을 통합적으로 구성하여 근육감 소증의 골격근 지수와 기능적 체력, 건강관련 삶의 질 에 어떻게 기여하는지에 대한 연구가 드문 실정이다.

따라서 허약노인의 건강증진에 필수적으로 요구되 는 심폐기능, 근기능, 균형기능 증진에 중점을 둔 유 산소 운동, 저항성 운동, 균형 운동을 모두 포함시킨 통합적 운동 프로그램으로 구성하여 근육감소증의 골 격근 지수와 기능적 체력 개선뿐만 아니라 주관적 건 강지표가 되는 건강관련 삶의 질에 대한 효과를 살펴 볼 필요가 있다고 생각된다.

이에 본 연구에서는 신체적 기능이 저하된 허약노 인 예방과 치료전략으로 제시되고 있는 유산소, 저항 성, 균형 운동을 통합적으로 구성한 운동 프로그램을 실시하였을 때 골격근 지수, 기능적 체력 및 건강관련 삶의 질 변화 양상에 대해 규명하고자 하였다.

\section{연구 방법}

\section{연구대상}

본 연구의 대상자는 $\mathrm{J}$ 지역 건강증진센터 노인운동 교실에 자발적으로 참가한 65 세 이상 노인 중 허약 여성노인 18 명을 운동군 $(\mathrm{n}=9)$ 과 대조군 $(\mathrm{n}=9$ 명 $)$ 으로 구 분하여 실시하였다. 연구대상자의 신체적 특성은 다음 과 같다<Table 1>.

허약 여성노인 선정은 Fried et al.(2001)의 허약노 인 진단 기준을 기본으로 하여 국내에서 활용 가능한

Table 1. Physical characteristics of subjects

$(\mathrm{M} \pm \mathrm{SD})$

\begin{tabular}{ccccc}
\hline Group & Age(yrs) & Height $(\mathrm{cm})$ & Weight $(\mathrm{kg})$ & $\mathrm{BM}\left(\mathrm{kg} / \mathrm{m}^{2}\right)$ \\
\hline \hline Exercise & 68.08 & 157.06 & 65.13 & 26.38 \\
$(\mathrm{n}=9)$ & \pm 1.20 & \pm 3.80 & \pm 4.08 & \pm 1.28 \\
Control & 69.72 & 158.51 & 63.07 & 25.11 \\
$(\mathrm{n}=9)$ & \pm 2.19 & \pm 3.64 & \pm 7.29 & \pm 2.84 \\
\hline
\end{tabular}

BMI; Body Mass Index 
지표들로 수정(Korea Institute for Health and Social affairs, 2008)된 체중 감소, 악력 저하, 심한 피로, 보 행속도 저하, 활동량 저하의 5 가지 범주 중 3 가지 이 상에 해당할 경우로 하였다. 허약노인의 선정 기준은 다음과 같다.

(1) 6개월간 2 3kg의 비자발적 체중감소

(2) 악력이 $19 \mathrm{~kg}$ 미만인 경우

(3) 한국판 역학연구용 우울척도 중 '모든 일이 힘 들게 느껴졌다', '앞 일이 암담하게 느껴졌다' 의 두 문항 중 하나 이상 2점 이상인 경우

(4) 의자에서 $3 \mathrm{~m}$ 왕복하기가 10 초 이상인 경우

(5) 활동량 저하에 대한 설문인 기초 측정표 1 20 문항을 기준으로 10 점 이상인 경우

\section{측정항목 및 방법}

\section{신체구성 검사}

신장과 체중은 자동신체계측기(Jawon Medical, Korea)를 이용하여 각각 $0.1 \mathrm{~kg}, 0.1 \mathrm{~cm}$ 까지 측정하고 체질량지수(Body Mass Index: BMI)를 계산하였다. 허 리둘레 검사는 제 12 번 늑골 하단부와 장골능 상부의 중간부위에서 $0.1 \mathrm{~cm}$ 까지 측정하였다. 체지방율(\% fat) 검사는 출력 전류를 $50 \mathrm{kHz}$ 에서 $800 \mathrm{uA}$ 로 규정한 신체 전기저항법(Bioelectrical Impedance Analysis, BIA)에 의거한 체지방측정기(Jawon Medical, Korea)를 사용 하여 분석하였다.

\section{골격근 지수 검사}

골격근 지수(Skeletal Muscle Index, SMI)는 Janssen et al.(2002)이 제시한 BIA를 참고로 하여 골격근육량 을 체중으로 나눈 배분율로 정의하여 검사하였다.

\section{기능적 체력 검사}

\section{심폐지구력 검사}

심폐지구력 검사는 운동부하가 점증적으로 증가되 는 고정식 자전거(cycle ergometer, TAKEI Model, Japan)로 측정하였다. 운동부하는 램프부하 방식을 이 용한 최대하운동부하검사로 귀에 부착된 심박수 감지 센서를 모니터링하고 회귀방정식에 의하여 예측 최대
심박수(220-나이)에 상응하는 $\mathrm{VO}_{2} \max$ 를 측정하였다.

\section{이동성 검사}

이동성 검사(timed up \& go)는 의자에서 $3 \mathrm{~m}$ 왕복 하기를 실시하였다. 의자에서 앉은 상태에서 시작이라 는 신호와 함께 의자에서 일어난 후 가능한 빨리 3 $\mathrm{m}$ 떨어진 콘까지 걸어갔다 콘을 돌아 다시 와서 의자 에 앉는 데 걸리는 시간을 초 단위로 측정하였다.

\section{근력 검사}

근력은 악력 검사(grip strength), 상지 근력 검사(arm curl test)와 하지 근력 검사(chair sit to stand)를 측정하 였다. 악력 검사는 악력계(Digital Grip Dynamometer, Takei Kiki Kogyo, Tokyo, Japan)를 이용하여 측정하 였다. 악력계를 잡은 후 두 번째 손가락의 제2관절이 거의 직각이 되도록 폭을 조절한 후 2회 측정하여 최 고값을 기록하였다. 상지 근력 검사는 의자에 앉은 자 세로 $2 \mathrm{~kg}$ 의 아령을 들고, 올렸다 내리는 것을 1 회로 하여 30 초 동안 기록하였다. 하지 근력 검사는 허리를 펴고 의자의 중간부분에 앉은 후 팔은 $\mathrm{X}$ 자형으로 가 슴에 놓고 시작이란 신호와 함께 30 초 동안 의자에 앉았다 일어서는 횟수를 측정하였다.

\section{유연성 검사}

유연성 검사는 상지 유연성 검사(back scratch)와 하지 유연성 검사(chair sit \& reach)를 실시하였다. 상지 유연성 검사는 등 위에서 손닿기로 한 손은 어 깨 위로 올리고 다른 손은 등의 중간 위로 올렸을 때 뻗은 중지사이의 간격을 $\mathrm{cm}$ 단위로 측정하였다. 하지 유연성 검사는 의자에 앉아서 발끝 손닿기로 앉아서 한 쪽 다리를 뻗고 양 손을 발끝을 향해 뻗은 발끝 사이의 간경을 $\mathrm{cm}$ 단위로 측정하였다.

\section{평형성 검사}

평형성 검사(one-leg stance)는 눈감고 외발서기를 실시하였다. 평형성 측정기구(Helmas III, Korea)의 센 서 발판 위에 한 발은 올려놓고 양 손은 허리에 위치 한 후 시작 부저음과 동시에 다른 한쪽 발을 뒤로 직 각이 되도록 올리게 한 후 다리가 바닥에 닿으면 센 서에 의해 자동 시간을 측정하였다. 


\section{건강관련 삶의 질 검사}

건강관련 삶의 질(The 36-item short form of the medical outcomes study questionnaire; SF-36) 검사는 Ware \& Sherbourne(1992)이 개발하고 Nam \& Lee(2003) 가 수정한 한국판 건강관련 삶 도구를 이용하여 측정하 였다. SF-36은 두 개의 신체적, 정신적 구성요소로 구분 되어 있다. 신체적 구성요소는 신체적 기능(physical functioning) 10 문항, 신체적 역할(role-physical) 4 문항, 통증(bodily pain) 2문항, 일반적 건강(general health) 5 문항, 활력(vitality) 5 문항으로 구성되어 있다. 정신적 구 성요소는 사회적 기능(social functioning) 2문항, 감정적 역할(role-emotional) 3 문항, 정신 건강(mental health) 5 문항으로 구성되어 있다.

SF-36 문항의 응답은 Likert 척도로 1점에서 5점까 지 나타냈다. 본 연구는 9 영역 중 건강변화에 해당되 는 1 문항은 점수화 과정에서 제외하고 8 영역의 점수 를 100점으로 변환시켜 점수로 반영하였다. SF-36 도 구개발 당시 신뢰계수 Cronbach's $a=.65$.94이었고, 본 연구의 신뢰계수 Cronbach's $a=.76$ 로 나타났다.

\section{운동 프로그램}

운동 프로그램은 준비운동, 본 운동, 정리운동 순으 로 구성하여 12 주간 주 3 회 실시하였다<Table 2>. 준 비운동은 걷기 5 분 후 스트레칭 10 분, 정리운동은 스 트레칭을 10 분간 실시하였다. 본 운동은 유산소 운동, 저항성 운동 및 균형 운동을 60 분간 실시하였다.

유산소 운동은 최대심박수 $60 \%$ 와 운동자각도(ratings of perceived exertion; RPE) 12 14에서 트레드밀 걷기 혹은 고정식 자전거 타기를 20 분간 실시하였다. 저항성 운동은 탄성 밴드(Thera-band, USA)를 이용하여 가슴, 어깨, 팔, 다리, 발목 부위를 각각 2세트, 8 12회 반복 회수로 20분간 RPE 12 14에서 실시하였다. 균형 운동 은 스위스 볼(Swiss-ball, Germany)을 이용하여 공위에 앉은 자세에서 골반(앞, 뒤, 옆 방향) 이동하기, 공위에 앉은 자세에서 양발을 교대로 들어 올려다 놓기, 팔다리 교차 들기를 반복하기를 각각 2 세트, 10 회 반복횟 수로 10분간 RPE 12 14에서 실시하였다.
Table 2. Exercise program

\begin{tabular}{|c|c|c|c|}
\hline Contents & Exercise program & $\begin{array}{l}\text { Exercise } \\
\text { intensity }\end{array}$ & $\begin{array}{c}\text { Exercise } \\
\text { time }\end{array}$ \\
\hline Warm-up & walk \& stretching & & $15 \mathrm{~min}$ \\
\hline $\begin{array}{l}\text { Aerobic } \\
\text { exercise }\end{array}$ & $\begin{array}{l}\text { treadmill walking } \\
\text { or stationary bicycle }\end{array}$ & $\begin{array}{l}\operatorname{HRmax} \\
60 \%\end{array}$ & $20 \mathrm{~min}$ \\
\hline $\begin{array}{l}\text { Resistance } \\
\text { exercise }\end{array}$ & $\begin{array}{l}\text { chest press } \\
\text { lateral shoulder raises } \\
\text { arm curl } \\
\text { triceps extension } \\
\text { squat } \\
\text { calf raise } \\
\text { ankle dorsiflexion \& } \\
\text { plantarflexion }\end{array}$ & $\begin{array}{c}\mathrm{RPE} \\
12 \sim 14\end{array}$ & $\begin{array}{c}20 \mathrm{~min} / \\
\text { 2sets } \\
8 \sim 12 \text { rep }\end{array}$ \\
\hline $\begin{array}{l}\text { Balance } \\
\text { exercise }\end{array}$ & $\begin{array}{l}\text { pelvis forward \& } \\
\text { backward } \\
\text { pelvis side to side } \\
\text { leg lifts } \\
\text { arms, legs cross-lifting }\end{array}$ & $\begin{array}{c}\mathrm{RPE} \\
12 \sim 14\end{array}$ & $\begin{array}{c}10 \mathrm{~min} / \\
2 \mathrm{sets} \\
10 \mathrm{rep}\end{array}$ \\
\hline Cool-down & stretching & & $10 \mathrm{~min}$ \\
\hline
\end{tabular}

\section{자료 분석}

본 연구의 자료처리는 SAS(version 9.1)를 이용하여 측정항목별 평균(M)과 표준편차(SD)를 산출하고 도표 화하였다. 평균차 검증은 반복측정에 의한 이원변량분 석(two-way ANOVA by repeated measure)을 실시하 였다. 유의수준 $(a)$ 은 .05로 정하였다.

\section{결과}

\section{신체구성 변화}

<Table 3>에서 보는 바와 같이 12 주간 운동 프로 그램 처치 후 체중, 체지방율, 허리둘레는 상호작용효 과 나타났으며(각각 $p<.05, p<.001, p<.05)$, 이에 대한 사후검증 결과 처치 전, 후 운동군은 유의하게 감소하 는 것으로 나타났다(각각 $p<.01, p<.001, p<.01)$. 그러 나 대조군은 유의한 차이가 나타나지 않았다.

골격근육량과 골격근지수는 주효과와 상호작용효과 가 나타나지 않았다. 


\section{기능적 체력 변화}

그램 처치 후 심폐지구력은 상호작용효과가 나타났으 며 $(p<.001)$, 이에 대한 사후검증 결과 처치 전, 후 운

<Table $4>$ 에서 보는 바와 같이 12 주간 운동 프로동군은 유의하게 증가하는 것으로 나타났다( $p<.01)$. 그

Table 3. Changes of body composition

\begin{tabular}{|c|c|c|c|c|c|c|c|}
\hline Variability & Group & Pre & Post & $\Delta \%$ & & $F$ & $p$ \\
\hline \multirow{3}{*}{$\begin{array}{l}\text { Weight } \\
\text { (kg) }\end{array}$} & \multirow[t]{2}{*}{ Exercise } & \multirow[t]{2}{*}{$65.13 \pm 4.08$} & \multirow[t]{2}{*}{$63.82 \pm 3.61^{* *}$} & \multirow[t]{2}{*}{-2.10} & $\mathrm{a}$ & 0.30 & .590 \\
\hline & & & & & $\mathrm{b}$ & 9.14 & .008 \\
\hline & Control & $63.07 \pm 7.29$ & $62.85 \pm 7.40$ & -0.34 & $a^{*} b$ & 4.61 & .047 \\
\hline \multirow{3}{*}{$\%$ fat } & \multirow[t]{2}{*}{ Exercise } & \multirow[t]{2}{*}{$35.16 \pm 2.10$} & \multirow[t]{2}{*}{$33.82 \pm 1.87^{\star * *}$} & \multirow[t]{2}{*}{-3.81} & $\mathrm{a}$ & 2.17 & .159 \\
\hline & & & & & $\mathrm{b}$ & 31.03 & .000 \\
\hline & Control & $32.68 \pm 3.26$ & $32.54 \pm 3.31$ & -0.42 & $a^{*} b$ & 20.15 & .000 \\
\hline \multirow{2}{*}{$\begin{array}{l}\text { Waist circumference } \\
(\mathrm{cm})\end{array}$} & Exercise & $88.64 \pm 3.87$ & $87.06 \pm 3.74^{* * *}$ & -1.78 & $\mathrm{a}$ & 0.14 & .709 \\
\hline & \multirow{2}{*}{ Control } & \multirow{2}{*}{$89.02 \pm 6.58$} & \multirow{2}{*}{$88.65 \pm 7.08$} & \multirow{2}{*}{-0.41} & $\mathrm{~b}$ & 15.47 & .001 \\
\hline \multirow{3}{*}{$\begin{array}{l}\text { Skeletal muscle } \\
\text { mass } \\
(\mathrm{kg})\end{array}$} & & & & & $a^{*} b$ & 6.00 & .026 \\
\hline & Exercise & $20.06 \pm 4.97$ & $20.55 \pm 5.31$ & 2.44 & $\mathrm{a}$ & 0.01 & .925 \\
\hline & Control & $20.23 \pm 3.35$ & $20.71 \pm 3.03$ & 2.37 & $x^{* \mathrm{~b}}$ & $\frac{1.33}{0.00}$ & .266 \\
\hline \multirow{3}{*}{$\begin{array}{l}\text { Skeletal muscle } \\
\text { index } \\
(\%)\end{array}$} & \multirow{2}{*}{ Exercise } & \multirow{2}{*}{$30.85 \pm 7.31$} & \multirow{2}{*}{$32.12 \pm 7.91$} & \multirow{2}{*}{4.11} & $\mathrm{a}$ & 0.14 & .712 \\
\hline & & & & & $\mathrm{b}$ & 3.97 & .063 \\
\hline & Control & $32.08 \pm 4.10$ & $33.00 \pm 3.65$ & 2.86 & $a^{*} b$ & 0.10 & .742 \\
\hline
\end{tabular}

Table 4. Changes of functional fitness

\begin{tabular}{|c|c|c|c|c|c|c|c|}
\hline Variability & Group & Pre & Post & $\Delta \%$ & & $F$ & $p$ \\
\hline \multirow{3}{*}{$\begin{array}{c}\mathrm{VO}_{2 m a x} \\
(\mathrm{ml} / \mathrm{kg} / \mathrm{min})\end{array}$} & \multirow[t]{2}{*}{ Exercise } & \multirow[t]{2}{*}{$20.24 \pm 2.21$} & \multirow[t]{2}{*}{$23.94 \pm 1.71^{* *}$} & \multirow[t]{2}{*}{18.28} & $\mathrm{a}$ & 0.07 & .788 \\
\hline & & & & & \multirow{2}{*}{$\frac{b}{a^{*} b}$} & \multirow{2}{*}{$\begin{array}{l}26.37 \\
17.08\end{array}$} & .000 \\
\hline & Control & $21.60 \pm 2.76$ & $22.00 \pm 2.91$ & 1.85 & & & .000 \\
\hline \multirow{3}{*}{ Timed up $\operatorname{up}_{(\mathrm{sec})} \&$ go } & \multirow[t]{2}{*}{ Exercise } & $9.59 \pm 1.64$ & $8.55 \pm 1.63^{* *}$ & -10.84 & $a$ & 0.75 & .398 \\
\hline & & & & & $\mathrm{b}$ & 25.64 & .000 \\
\hline & Control & $9.70 \pm 1.15$ & $9.55 \pm 1.07$ & -1.54 & $a * b$ & 14.15 & .001 \\
\hline \multirow{2}{*}{$\begin{array}{l}\text { Grip strength } \\
\text { (kg) }\end{array}$} & Exercise & $18.36 \pm 2.52$ & \multirow[t]{2}{*}{$20.56 \pm 2.06^{* * *}$} & 11.98 & $\mathrm{a}$ & 0.05 & .819 \\
\hline & \multirow{2}{*}{ Control } & \multirow{2}{*}{$19.57 \pm 1.65$} & & \multirow{2}{*}{1.17} & $\mathrm{~b}$ & 62.16 & .000 \\
\hline \multirow{3}{*}{$\begin{array}{l}\text { Arm curl } \\
\text { (reps/30sec) }\end{array}$} & & & $19.80 \pm 1.88$ & & $a * b$ & 41.44 & .000 \\
\hline & \multirow[t]{2}{*}{ Exercise } & $20.22 \pm 1.64$ & $22.44 \pm 1.74 * *$ & \multirow[t]{2}{*}{10.97} & $\mathrm{a}$ & 0.07 & .799 \\
\hline & & $20.89 \pm 1.83$ & \multirow{2}{*}{$21.33 \pm 2.35$} & & $\mathrm{~b}$ & 25.89 & .000 \\
\hline \multirow{3}{*}{$\begin{array}{l}\text { Chair sit to stand } \\
\text { (reps/30sec) }\end{array}$} & Control & \multirow{2}{*}{$16.11 \pm 2.09$} & & 2.10 & $a^{*} b$ & 11.51 & .003 \\
\hline & Exercise & & $19.00 \pm 2.00^{\star \star \star *}$ & 17.93 & $\mathrm{a}$ & 0.53 & .476 \\
\hline & Control & $16.88 \pm 1.36$ & $17.11 \pm 1.45$ & 1.36 & $\frac{D}{* t h}$ & 22.89 & .000 \\
\hline & Exercise & $-6.50 \pm 6.10$ & $285+520 *$ & 5615 & $a$ & $\begin{array}{r}10.02 \\
0.07\end{array}$ & .000 \\
\hline $\begin{array}{c}\text { Back scratch } \\
(\mathrm{cm})\end{array}$ & & & & 50.15 & $\mathrm{~b}$ & 8.63 & .005 \\
\hline & Control & $-4.48 \pm 7.42$ & $-3.16 \pm 8.92$ & 29.46 & $a^{*} b$ & 1.89 & .188 \\
\hline Chair sit \& reach & Exercise & $15.27 \pm 8.17$ & $17.37 \pm 7.53^{\star *}$ & 13.75 & $\mathrm{a}$ & 0.61 & .447 \\
\hline$(\mathrm{cm})$ & Control & $13.46 \pm 5.87$ & $1404+634$ & 420 & $\mathrm{~b}$ & 17.21 & .000 \\
\hline & Wiाn & $10.40=0.0 \%$ & $14.04-0.34$ & 4.30 & $a^{*} b$ & 5.56 & .031 \\
\hline One-leg stance & Exercise & $2.77 \pm 2.28$ & $5.22 \pm 2.77^{\star \star}$ & 88.44 & $\mathrm{a}$ & 0.00 & .956 \\
\hline & Control & $3.66 \pm 2.24$ & $4.22 \pm 1.72$ & 15.30 & $\frac{D}{2 * b}$ & $\frac{10.02}{6.25}$ & .001 \\
\hline
\end{tabular}


러나 대조군은 유의한 차이가 나타나지 않았다.

이동성은 상호작용효과가 나타났으며 $(p<.001)$, 이에 대한 사후검증 결과 처치 전, 후 운동군은 유의하게 감소하는 것으로 나타났다( $p<.01)$. 그러나 대조군은 유 의한 차이가 나타나지 않았다.

근체력 변인에서 악력, 상지 근력 및 하지 근력은 상 호작용효과가 나타났으며(각각 $p<.001, p<.01, p<.001)$, 이 에 대한 사후검증 결과 처치 전, 후 운동군은 유의하게 증가하는 것으로 나타났다(각각 $p<.001, p<.001, p<.001)$. 그러나 대조군은 유의한 차이가 나타나지 않았다.

유연성 변인에서 상지 유연성은 주효과에서 처치 간 운동군이 사전에 비해 사후에 유의하게 증가하였 으며 $(p<.01)$, 상호작용효과는 나타나지 않았다. 하지 유연성은 상호작용효과가 나타났으며 $(p<.05)$, 이에 대 한 사후검증 결과 처치 전, 후 운동군은 유의하게 증 가하는 것으로 나타났다( $p<.01)$. 그러나 대조군은 유의 한 차이가 나타나지 않았다.

평형성은 상호작용효과가 나타났으며( $p<.05)$, 이에
대한 사후검증 결과 처치 전, 후 운동군은 유의하게 증가하는 것으로 나타났다( $p<.05)$. 그러나 대조군은 유 의한 차이가 나타나지 않았다.

\section{건강관련 삶의 질 변화}

<Table 5>에서 보는 바와 같이 12 주간 운동 프로 그램 처치 후 신체적 기능, 통증, 일반적 건강, 정신 건강은 상호작용효과가 나타났으며(각각 $p<.001$, $p<.001, p<.001, p<.001)$, 이에 대한 사후검증 결과 처 치 전, 후 운동군은 유의하게 증가하는 것으로 나타났 다(각각 $p<.01, p<.001, p<.001, p<.01)$. 그러나 대조군 은 유의한 차이가 나타나지 않았다. 정서적 역할은 주 효과에서 처치 간 운동군이 사전에 비해 사후에 유의 하게 증가하였으며 $(p<.01)$, 상호작용효과가 나타나지 않았다.

신체적 역할, 활력 및 사회적 기능은 주효과와 상 호작용효과가 나타나지 않았다.

Table 5. Changes of health-related quality of life

\begin{tabular}{|c|c|c|c|c|c|c|c|}
\hline Variability & Group & Pre & Post & $\Delta \%$ & & $F$ & $p$ \\
\hline \multirow{3}{*}{$\begin{array}{l}\text { Physical functioning } \\
\text { (score) }\end{array}$} & \multirow{2}{*}{ Exercise } & \multirow{2}{*}{$43.33 \pm 4.15$} & \multirow{2}{*}{$57.78 \pm 7.85^{\star *}$} & \multirow{2}{*}{33.34} & $\mathrm{a}$ & 8.54 & .010 \\
\hline & & & & & $\mathrm{b}$ & 42.99 & .000 \\
\hline & Control & $43.05 \pm 4.97$ & $45.27 \pm 3.41$ & 5.15 & $a * b$ & 23.12 & .000 \\
\hline \multirow{3}{*}{$\begin{array}{l}\text { Role-physical } \\
\text { (score) }\end{array}$} & \multirow[t]{2}{*}{ Exercise } & \multirow[t]{2}{*}{$72.22 \pm 19.54$} & \multirow[t]{2}{*}{$83.33 \pm 12.50$} & \multirow[t]{2}{*}{15.38} & a & 0.00 & .945 \\
\hline & & & & & b & 0.82 & .378 \\
\hline & Control & $71.67 \pm 19.53$ & $75.00 \pm 17.68$ & 4.64 & $a * b$ & 0.00 & .977 \\
\hline \multirow{3}{*}{$\begin{array}{l}\text { Bodily pain } \\
\text { (score) }\end{array}$} & \multirow{2}{*}{ Exercise } & \multirow[t]{2}{*}{$52.08 \pm 12.10$} & \multirow[t]{2}{*}{$75.83 \pm 4.68^{\star * *}$} & \multirow[t]{2}{*}{45.60} & a & 10.94 & .004 \\
\hline & & & & & $\mathrm{b}$ & 37.19 & .000 \\
\hline & Control & $47.22 \pm 10.42$ & $52.77 \pm 12.15$ & 11.75 & $a * b$ & 14.33 & .001 \\
\hline \multirow{3}{*}{$\begin{array}{l}\text { General health } \\
\text { (score) }\end{array}$} & \multirow[t]{2}{*}{ Exercise } & \multirow{2}{*}{$48.33 \pm 9.10$} & \multirow{2}{*}{$61.11 \pm 6.01^{\star * *}$} & \multirow[t]{2}{*}{26.44} & a & 0.58 & .457 \\
\hline & & & & & b & 56.82 & .000 \\
\hline & Control & $50.55 \pm 12.36$ & $51.67 \pm 12.25$ & 2.21 & $a * b$ & 40.09 & .000 \\
\hline \multirow{3}{*}{$\begin{array}{l}\text { Vitality } \\
\text { (score) }\end{array}$} & Exercise & $50.69 \pm 5.80$ & $57.63 \pm 8.14$ & 13.69 & a & 0.02 & .889 \\
\hline & & & & & b & 1.73 & .207 \\
\hline & Control & $54.1 / \pm 15.31$ & $52.7 / \pm 12.15$ & -2.58 & $a * b$ & 3.91 & .065 \\
\hline Social functioning & Exercise & $66.67 \pm 18.75$ & $72.22 \pm 13.66$ & 8.32 & a & 0.59 & .451 \\
\hline (score) & & & & & $\mathrm{b}$ & 2.41 & .140 \\
\hline & Control & $62.50 \pm 18.75$ & $63.88 \pm 19.21$ & 2.20 & $a * b$ & 0.86 & .367 \\
\hline Role-emotional & Exercise & $75.00 \pm 21.65$ & $86.11 \pm 13.18^{\star *}$ & 14.81 & a & 2.15 & .161 \\
\hline (score) & & & ר 15+ר? 7 & & $\mathrm{~b}$ & 8.47 & .010 \\
\hline & Control & $66.6 / \pm 1 / .68$ & $72.22 \pm 15.02$ & 8.32 & $a * b$ & 0.94 & .346 \\
\hline Mental health & Exercise & $45.00 \pm 11.99$ & $58.88 \pm 9.61^{\star *}$ & 30.84 & a & 0.68 & .421 \\
\hline (score) & Control & $56.11 \pm 8.21$ & $5555+1210$ & 099 & $\mathrm{~b}$ & 15.78 & .001 \\
\hline & Control & & & & $a * b$ & 18.52 & .000 \\
\hline
\end{tabular}




\section{논의}

허약노인은 일상생활활동이 저하된 고령자로 주된 핵심증후는 근육감소증이며, 정상노인에 비해 기능적 체력과 삶의 질도 저하되어 있는 것으로 나타났다 (Lally \& Crome, 2007). 운동은 기능적 장애가 없는 활동적인 건강 노화에 필수적이다(Van Roie et al., 2010). 이에 본 연구는 유산소 운동, 저항성 운동, 균 형 운동으로 구성된 운동 프로그램이 허약노인 근육 감소증 지표인 골격근 지수, 기능적 체력 및 건강관련 삶의 질에 대한 효과를 알아보고자 하였다.

허약노인의 주된 문제로 거론되고 있는 근육감소증 은 제지방량 중 골격근육량 감소로 인한 것이며, 낮은 골격근육량은 전체 사망률과 유의한 연관성이 있는 것 으로 나타났다(Jung et al., 2013; Rolland et al., 2008). 근육감소증 발생은 신체활동 감소의 영향이 높은 것으 로 밝혀지고 있다(Landi et al., 2012; Siparsky et al., 2014). 즉 신체활동이 저하되면 골격근은 단백질 분해 를 증가시키고 단백질 합성을 감소시켜, 골격근의 질 량 낮아지게 된다. 하지만 운동은 골격근육량 높이고 지방량을 감소시켜, 근육감소증 예방에 필수적인 중재 요소가 되고 있다(Visvanathan \& Chapman, 2010).

본 연구의 결과에 의하면 운동은 허약노인의 체중, 체지방율, 허리둘레 감소에는 유의한 효과가 나타났지 만 Janssen et al.(2002)이 제시한 생체 임피던스 분석 (Bioelectrical Impedance Analysis, BIA)으로 골격근육 량을 평가하고 이를 체중으로 나누어 계산한 골격근 지 수는 유의한 차이가 나타나지 않았다. Lee \& Ko(2012) 의 연구에서도 8 주간 고령 여성의 유산소와 저항성 운 동에 의해 BIA로 측정한 골격근 지수는 유의한 변화가 나타나지 않았다. 반면 Hunter et al.(2000)의 연구에서 는 26 주간 저항성 운동이 노인의 체지방량 감소와 근육 량 증가를 보였으며, Leenders et al.(2013)도 24주간 저 항성 운동에 의해 노인의 근육량이 증가하는 것으로 나 타났다. 이처럼 노인의 근육량 증가는 장기간 저항성 운동에 의해 효과적인 것으로 제시되고 있다. 그러므로 허약노인의 골격근육량을 높이는 데는 장기간 운동 적 응이외에도 유산소, 저항성, 균형 운동 프로그램 구성 시 골격근육량 증진에 주된 요인이 되고 있는 저항성
운동량도 고려할 필요가 있다고 본다. 또한 골격근육량 은 식이 단백질 섭취량에 의해서도 영향을 미치므로 (Morais et al., 2006), 차후에는 이러한 점도 고려하여 연구를 진행할 필요가 있다고 본다.

한편 허약노인의 신체적 기능 저하는 근육감소증의 골 격근육량 감소이외에도 근력 저하도 직접적으로 연관이 있으며(Studenski et al., 2011; Visser \& Schaap, 2011), Bouchard et al.(2010)의 미국 국민보건영양조사 자료를 이용한 단면적 연구에서도 낮은 근력은 신체장애와 연관 이 높은 것으로 나타났다. 허약노인의 경우 건강노인에 비해 근력뿐만 아니라 신체적 기능 장애의 예견지표가 기 능적 체력이 낮을 경우 일상생활활동에 어려움이 뒤따르 게 된다(Evans, 1999). 즉 노년기 일상생활활동을 독립적 으로 수행하기 위해서는 기능적 체력을 높이는 것이 중요 하다. 운동은 여러 연구에서 노인의 기능적 체력을 증진 시키는 데 입증되고 있다(Cornillon et al., 2002; Jones \& Rose, 2005; Park et al., 2014; Province et al., 1995).

본 연구의 결과에 의하면 운동은 허약노인의 기능적 체력요소의 심폐지구력, 이동성, 악력, 상·하지 근력, 상 - 하지 유연성 및 평형성 증진에 유의한 효과가 나 타났다. Kim et al.(2014)의 연구에서도 12주간 세라밴 드, 에어로 스텝, 짐볼 운동으로 구성된 운동 프로그램 이 60세 이상 지역사회 건강노인과 허약노인의 근력과 보행능력 및 균형능력을 개선시키는 것으로 나타났다. Sun et al.(2008)도 12주간 근력운동은 허약노인의 악 력, 이동성, 평형성을 증가시키는 것으로 나타났다. 허 약노인에서 기능적 체력을 높이기 위해 권고되는 유산 소 운동은 심폐기능과 골격근의 산화기능을 개선해주 며, 저항성 운동은 근력을 증가시키는 데 실질적인 요 인이 되고 있다. 균형 운동의 경우 근신경계 기능을 높 이는 데 효과적인 것으로 제시되고 있다(Lord \& Sturnieks, 2005; Rolland et al., 2008). 따라서 본 연구 에서 심폐계 기능, 근골격계 기능 및 근신경계 기능 향 상을 위한 통합적 운동 프로그램은 허약노인의 기능적 체력 증진에 효과적인 것으로 볼 수 있다. 특히 저항성 과 균형 운동에 의한 허약노인의 상, 하지 근력과 평형 성 증진은 보행능력과 균형 감각을 높여 독립적인 일상 생활을 영위하는 데 주된 역할을 할 것으로 생각된다.

또한 허약노인은 앞에서 언급된 신체적 기능 저하로 일상생활활동을 수행을 위한 필요한 동작들에서 불편 
함을 겪게 되므로 타인에게 의존하거나 의존할 위험성 이 높아지게 된다(Brown et al., 1995; Rockwood \& Robertson, 1994; Rockwood et al., 2000). 그 결과 허 약노인은 그렇지 않은 건강노인보다 신체적, 정신적 및 사회적 기능도 저하되어 삶의 질도 상당히 낮은 것으 로 나타났다(Meredith et al., 2009; Puts et al., 2007). 운동은 삶의 질을 드높이데 기여한다는 사실은 여러 연구에서 입증되어 왔다(Acree et al., 2006; Atlantis et al., 2004; Daskapan et al., 2005).

본 연구의 결과에 의하면 운동은 허약노인의 건강관 련 삶의 질(SF-36)에서 신체적 기능, 활력, 통증, 일반 적 건강, 정서적 역할 및 정신 건강은 유의하게 증가되 었지만 신체적 역할, 사회적 역할 및 정서적 기능은 유 의한 차이가 나타나지 않았다. Kim \& Lee(2010)의 연 구에서도 12 주간 밴드 운동이 허약노인의 SF-36에서 신체적 기능, 신체적 역할, 활력, 정신적 건강 요소가 유의하게 증가하는 것으로 나타났다. Fraga et al.(2011) 도 60 세 이상 여성노인의 걷기 프로그램이 삶의 질을 높이는 데 효과적인 것으로 나타나 본 연구 결과를 뒷 받침해주고 있다. 즉 허약노인은 신체적 기능저하로 인 해 주관적 건강인식에 부정적인 영향을 미치게 되지만 운동은 기능적 체력을 증진시키며, 그 결과 일상생활수 행력을 높여 주관적 건강지표인 건강관련 삶의 질에도 긍정적인 영향을 미치는 것으로 생각된다.

이와 같이 본 연구에서 12 주간 유산소, 저항성, 균 형 운동 프로그램은 허약노인의 근육감소증에 대한 골격근육량과 골격근 지수 변화에는 뚜렷하게 나타나 지 않았다. 하지만 골격근육량을 유지하면서 기능적 체력과 건강관련 삶의 질에 높이는 데 효과적인 것으 로 확인할 수가 있었다. 차후 연구에서는 근육감소증 의 골격근육량을 높이는 운동뿐만 아니라 골격근의 단백질 합성에 영향을 미치는 단백질 섭취량 등의 요 인도 분석하여 진행될 필요가 있다고 본다.

\section{결론}

본 연구에서 유산소, 저항성, 균형 운동으로 구성된 통합적 운동 프로그램은 허약노인의 근육감소증의 골
격근육량과 골격근 지수 증가에는 효과적이지 않았다. 그러나 기능적 체력과 건강관련 삶의 질을 높이데 효 과적인 것으로 나타났다. 따라서 운동은 허약노인의 일상생활수행능력을 위한 기능적 체력증진에 효과적 인 중재방안이라고 생각된다. 또한 운동은 허약노인의 건강관련 삶의 질 향상을 높이기 위해서도 중요하다 고 판단되며, 추후 골격근육량의 단백질 합성 영향을 미치는 운동이외 식이 단백질 섭취량 등을 통해 후속 연구가 진행되어야 할 것으로 사료된다.

\section{참고문헌}

Acree, L. S., Longfors, J., Fjeldstad, A. S., Fjeldstad, C., Schank, B., Nickel, K. J., Montgomery, P. S., \& Gardner, A. W. (2006). Physical activity is related to quality of life in older adults. Health Quality of Life Outcomes, 4: 1-6. American College of Sports Medicine. (1998). ACSM Position Stand: Exercise and physical activity for the older adults. Medicine Science \& Sports Exercise, 30(6): 992-1008.

Atlantis, E., Chow, C. M, Kirby, A. \& Singh, M. F. (2004). An effective exercise-based intervention for improving mental health and quality of life measures: a randomized controlled trail. Prevention Medicine, 39(2): 424434.

Bouchard, D. B, Mariane, H, \& Jassen, I. (2010). Association Between Muscle Mass, Leg Strength, and Fat Mass With Physical Function in Older Adults: Influence of Age and Sex. Journal of Aging and Health, 20(10): 1-16.

Brwon, I., Renwick, R., \& Raphael, D. (1995). Frailty: constructing a common meaning, definition, and conceptual framework. International Journal of Rehabilitation Research, 18: 93-102.

Burton, L. A., \& Sumukadas, D. (2010). Optimal management of sarcopenia. Clinical Interventions in Aging, 5: 217-228. 
Cornillon, E, Blanchon, M A, Ramboa, T. T., Braize, C, Beauche, O., Dubost, V., Blanc, P., \& Gonthier, R (2002). Effectiveness of falls prevention strategies for elderly subjects who live in the community with performance assessment of physical activities(before-after). Anmales de Réadaptation et de Médecine Physique, 45: 493-504.

Cruz-Jentoft, A. J., Baeyens, J. P., Bauer, J. M., Boirie, Y., Cederholm, T., Landi, F., Martin, F. C., Michel,J. P., Rolland, Y., Schneider, S. M, Topinkova, E., Vandewoude, M. \& Zamboni, M. (2010). Sarcopenia: European consensus on definition and diagnosis: report of the european working group on sarcopenia in older people. Age Ageing, 39: 412-423.

Daskapan, A., Tuzun, E. H., \& Eker, L. (2005). Relationship between physical activity level and health related quality of life among university students. Saudi Medicine Journal, 26(6): 1026-1028.

Ensrud, K. E, Ewing, S. K., Taylor, B. C., Fink, H. A., Stone, K. L., Caule, J. A., Tracy, J. K., Hochberg, M. C., Rodondi, N., \& Cawthon, P. M. (2007). Frailty and risk of falls, fracture, and mortality in older women: the study of osteoporotic fractures. The Journals of Gerontology Series A: Biological Sciences and Medical Sciences, 62: 744751.

Evans, W. J. (1999). Exercise training guidelines for the elderly. Medicine Science \& Sports Exercise, 31(1): 12-17.

Fairhall, N., Aggar, C., Kurrle, S. E., Sherrington, C., Lord, S., Lockwood, K., Monagham, N., \& Cameron, I. D. (2008). Frailty intervention trail. BMC Geriatic, 8(1): 27.

Femia, E. E., Zarit, S. H., \& Johansson, B. (2001). The disabilement process in very late life: A study of the oldest-old in Sweden. Journal of Gerontology: Psychological Science, 563(1): 12-23.

Fraga, M. J., Cader, S. A., Ferreia, M. A., Giani, T. S.,
\& Dantas, E. H. M. (2011). Aerobic resistance, functional autonomy and quality of elderly women impacted by a recreation and walking program. Archives of Gerontology and Geriatrics, 52: 40-43.

Fried, L. P., Tangen C. M., Walston, J., Newman, A. B., Hirsch, C., Gottdiene, J., Seeman, T., Tracy, R., Kop, W. J., Burke, G., \& McBurnie, M. A. (2001). Frailty in older adults: evidence for aphenotype. The Journals of Gerontology Series A: Biological Sciences and Medical Sciences, 56: 146-156.

Gill, T. M., Baker, D. I., Gottschalk, M., Peduzzi, P. N., Allore, H., \& Byers, A. (2002). A program to prevent functional decline in physically frail, elderly persons who live at home. The New England Journal of Medicine, 347(14): 1068-1074.

Helbostad, J. L., Sletvold, O., \& Mpe-Nilssen, R. (2004). Effects of home exercises and group training on functional abilities in home-dwelling older persons with mobility and balance problems. A randomized study. Aging Clinical Experience Research, 18(2): 113-121.

Hunter, G. R., Wetzstein, C. J., Fields, D. A., Brown, A. \& Bamman, M. M. (2000). Resistance training increases total energy expenditure and free-living physical activity in older adults. Journal of Applied Physiology, 89: 977-984.

Janssen, I., Heymsfield, S., \& B., Ross, R. (2002). Low relative skeletal muscle mass(sarcopenia) in older persons is associated with functional impairement and physical disability. Journal of American Geriatrics Society, 50: 889-896.

Jones, C. J., \& Rose, D. J. (2005). Physical activity instruction of older adults. Champaign, IL: Human Kinetics.

Jung, H. W., Kin, S. W., Chin, H. J., Kim, C. H., \& Kim, K. I. (2013). Skeletal muscle mass as a predictor of mortality in the elderly 
population. The Korean Journal of Medicine, 85(2): 167-173.

Kim, J. S., \& Lee, S. B. (2010). The effect of band exercise on health status, activities of daily living \& health-related quality of life in the frail elderly. Korean Society for Wellness, 5(1): 93-101.

Kim, S. H., Suh, Y. S., \& Kim, D. H. (2014). Effect of exercise program on physical strength and function in elderly. Korean Journal of Clinical Geriatrics, 15(2): 62-68.

Klein, B. E., Klein R., Knudtson, M. D., \& Lee, K. E. (2005). Frailty, morbidity, and survival. Archives of Gerontology Geriatrics, 41: 141-149.

Koopman, R., \& Van Loon, L. J. C. (2009). Aging, exercise and muscle protein metabolism Journal of Applied Physiology, 106: 2040-2048.

Korea Institute for Health and Social Affairs. (2007). Health related quality of life and health-adjusted life expectancy. Seoul.

Lally, F., \& Crome, P. (2007). Understanding frailty. Postgraduate Medical Journal, 83(975): 16-20.

Landi, F., Liperoti, R., Fusco, D., Mastropaolo, S., Quattrociocchi, D., Proia, A., Russo, A., Bernabel, R., \& Onder, G. (2012). Prevalence and risk factors of sarcopenia among nursing home older residents. The Journals of Gerontology. Series A, Biological Sciences and Medical Sciences, 67(1): 48-55.

Lee, S. H., \& K S. (2012). Effects of Combined Exercise on Body Compositions and Isokinetic Leg Muscular Strength in Elderly Women by Fat Percent. The Korean Journal of Growth and Development, 20(2): 117 126.

Leenders, M, Verdijk, L B., van Der Hoeven, L, van Kranenburg, J., Nilwik, R, Wodzig, W. K, Senden, J. M, Keizer, H A, van Loon, \& L J. (2013). Protein supplementation during resistance-type exercise training in the elderly. Medicine Science \& Sports Exercise. 45(3): 542-552
Lord, S. R., Clark, R. D., \& Webster, I. W. (1991). Physiological factors associated with falls in an elderly population. Journal of American Geriatric Society, 39: 1194-1200.

Lord, S. R., \& Sturnieks, D. L. (2005). The physiology of falling: assessment and prevention strategies for older people. Journal of Science and Medicine in Sport, 8(1): 35-42.

Madureira, M. M., Takayama,L., Gallinaro, A. L, Caparbo, V. F., Costa, R. A., \& Pereira, R. $M$. (2007). Balance training program is highly effective in improving functional status and reducing the risk of falls in elderly women with osteoporosis: a randomized controlled trial. Osteoporosis international, 18(4): 419-425.

Masel, M. C., Graham, J. E., Reistetter, T. A., Markides, K. S., \& Ottenbacher, K. J. (2009). Frailty and health related quality of life in older Mexican Americans. Health Quality Life Outcomes, 7: 70-77.

Meredith, C. M. James, E. C., Timothy, A. R., Kyriakos, S. M., \& Kenneth, J. O. (2009). Frailty and health related quality life in older Mexican Americans. Health and Quality of Life Outcome, 7: 70-88.

Ministry of Health, Welfare, and Family Affairs. (2008). National health statistics: national health and nutrition survey. Seoul.

Morais, J. A., Chevalier, S., \& Gougeon, R. (2006). Protein turnover and requirements in the healthy and frail elderly. Journal of Nutrition Health Aging, 10: 272-283.

Nam, B. H., \& Lee, S. W. (2003). Testing the validity of the Korean SF-36 Health Survey. Journal of the Korean Society of Health Statistics, 28(2): 3-24.

Nelson, M. E., Rejeski, W. J., Blair, S. N., Duncan, P. W., Judge, J. O., King, A. C., Macera, C. A., \& Castaneda-Soeppa, C. (2007). Physical activity and public health in older adults: 
recommendation from the American College of Sports Medicine and the American Heart Association. Circulation, 116: 1094-1105.

Park, S. J., Song, H. S., Kim, K., J., Jin, Y. Y., \& Kim, H. J. (2014). Effects of korean national award program group exercise on daily fitness and balance confidence among the elderly participants. Korean Journal of Sports Science, 25(4): 650-663.

Park, S, J., Ko, B. G., Chung, J. W., Kim, S, H., Park, S, H., Lee, M. H., Kim, S. H., Park, C. H., \& Choi, K. H. (2015). Fitness Cut-off Values for Frailty in Korean Elderly Women: National Fitness Award for Elderly. Korean Journal of Sport Science, 26(2): 243-253.

Park, S. K., Kim, E, H., \& Kwon, Y. C. (2006). The effects of combined exercise on self-reliance fitness, insulin resistance and blood pressure in frail elderly women. The Korean Journal of Physical Education, 45(5): 369-380.

Province, M. A., Hadley, E. C., Hornbrook, M. C., Lipsitz, L. A., Miller, J. P., \& Mulrow, C. D. (1995). The effects of exercise on falls in elderly patients. Journal of the American Medicine Association, 273(17): 1341-1347.

Puts, M. T., Shekary, N., Widdershoven, G., Heldens, J., Lips, P., \& Deeg, D. J. (2007). What does quality of life mean to older frail and non-frail community-dwelling adults in the Netherlands? Quality Life Research, 16: 263-277.

Rejeski, W. J., \& Mihalko, S. L. (2001). Physical activity and quality of life in older adults. Journal of Gerontology, Series A, Biological Sciences and Medical Sciences, 56: 23-35.

Rikli, R. E., \& Jones, C. J. (2001). Senior fitness test manual. Illinois: Human Kinetics.

Rockwood, K., \& Robertson, D. (1994). Frailty in elderly people: an evolving concept. Canadian Medical Association Journal, 150(4): 489-495.

Rockwood, K., Hogan, D. B., \& MacKnight, C.
(2000). Conceptualization and measurement of frailty in elderly people. Drugs \& Aging, 17(4): 295-302.

Rolland, Y., Czerwinski, S., Abellan Van Kan, G., Morley, J. E, Cesari, M, Onder G, Woo, J., Baumgartner, R, Pillard, F., Boirie, Y., Chumlea, W. M, \& Vellas, B. (2008). Sarcopenia: its assessment, etiology, pathogenesis, consequences and future perspectives. The Journal of Nutrition Health and Aging, 12: 433-450.

Sakato, Y., Tanabe, K., Hangai, M. \& Kuno, S. (2007). Effects of weight bearing and rubber band training on frail elderly. Joneses Gournal psychology, 62: 69-74.

Scott, D., Hayes, A., Sanders, K. M, Aitken, D., Ebeling, P. R, \& Jones, G. (2014). Operational definitions of sarcopenia and their associations with 5-year changes in falls risk in community-dwelling middle-aged and older adults. Osteoporosis International, 25(1): 187-193.

Siparsky, P. N., Kirkendall, D. T., \& Garrett, W. E. (2014). Muscle changes in aging: Understanding sarcopenia. Sports Health, 6 (1): 36-40.

Studenski, S., Perera, S., Patel, K., Rosano, C., Faulkner, K, Inzitari, M, Brach, J., Chandler, J., Cawthon, P., Connor, E. B., Nevitt, M, Visser, M, Kritchevsky, S., Badinelli, S., Harris, T., Newman, A. B., Cauley, J., Ferrucci, L., \& Guralnik J. (2011). Gait speed and survival in older adults. Journal of the American Medicine Association, 305: 50-58.

Sun, W. D., Lee, S. H., Park, J. S., Bae, S., S., Cho, Y. H., Kin, C. B., Koh, K. W., \& Kim, Y. A. (2008). Analysis of the effects of muscle strength exercise on physical function and quality of life in the frail elderly. Journal of Korea Society for Health Education and Promotion, 25(1): 39-53.

United Nations. (2012). World population prospects: the 2012 revision, population division of 
the department of economic and social affairs of the united nations secretariat, http://esa.un.org/unpd/wpp/index.htm.

Van Roie, E., Delecluse, C., Opdenacker, J., De Bock, K., Kennis, E., \& Boen, F. (2010). Effectiveness of a lifestyle physical activity versus a structured exercise intervention in older adults. Journal of Aging and Physical Activity, 18: 335-352.

Visser, M. \& Schaap, L. A. (2011). Consequences of sarcopenia. Clinics in Geriatric Medicine, 27 (3): 387-399.

Visvanathan, R., \& Chapman, I. (2010). Preventing sarcopenia in older people. Maturitas, 66 (4): $383-388$.

Ware, J. E., \& Sherbourne, C. D. (1992). The MOS 36-item short-form health survey(SF-36).
Medicine Care, 30(6): 473-483.

Waston, J., Haddley, E. C., Ferrucci, L., Guaranlink, J. M., Newman, A. B., Studenski, S. A., Ershler, W. B., Harris, T., \& Fried, L. P. (2006). Research agenda for frailty in older adults: Toward a better understanding of physiology and etiology: Summary from the American Geriatrics Society/National Institude on Aging Research Conference on Frailty in oder adults. Journal of the American Geriatrics Society, 54: 991-1001.

World Health Organizaion. (2010). Grobal recommendations on physical activity. Geneva, Swizerland.

Yim, E. S., \& No, K. H. (2010). The effects of related factors on health-related quality of life for the frail elderly. Journal of Korean Academy Community Health Nursing, 21(1): 12-20. 